\title{
Decimalization under Cromwell
}

\author{
C. W E BS T E R
}

Corpus Christi College, Oxford

\section{Although Britain is only now adopting a decimal currency, the idea was first mooted three hundred years ago.}

IN the climate of speculation aimed at solving the economic crisis provoked by the civil wars, decimal coinage was proposed by the littlc known Oxford scholar, Robert Wood (c. 1622-85) in a short tract entitled "Ten to One". This is undated, but it was probably composed in 1655 or 1656. The single manuscript copy which has survived is complete and in a form ready for circulation or publication. Its full title is "TEN TO ONE. A short and ready way For the extraordinary Facilitation \& Dispatch of RECKONINGS. By meanes of Two or Three NEW DECIMAL COINES much desired in order to the Publick Good by R. W." $1 *$

This prophetic tract and its author have been completely overlooked by commentators on seventeenth century economics, Wood being known only as a minor mathematician ${ }^{2}$. However, he attained more celebrity than is generally recognized during the interregnum. After attending Eton, where he was a school friend of Robert Boyle, Wood entered Merton College, Oxford, graduating in 1647. At this time wholesale expulsion of Royalist academics gave widespread opportunities for preferment at Oxford, Wood being intruded as fellow of Lincoln College in 1650 . He followed the course of many able mathematicians, studying under William Oughtred, rector of Aldbury near Guildford. He was obviously successful, being entrusted with the English translation of Oughtred's famous textbook, Clavis Mathematica ${ }^{3}$.

Wood's association with Oughtred probably provides the key to his advocation of decimalization. Oughtred's book began with an introduction to decimal calculation and decimal fractions, which were recognized as having advantages over the sexagesimal method used by astronomers. Clavis Mathematica also provided an introduction to decimal logarithms, based on the recent work of Napier and Briggs. Oughtred had been a pupil of Briggs and his first publication was perhaps An Appendix to the Logarithms in Briggs's edition of Wright's translation of Napier's famous Mirifici logarithmorum canonis descriptio. During Wood's youth, the recognition of the value of logarithms and the calculation of comprehensive tables was one of the great achievements of European mathematics. Wood recognized that currency decimalization would assist the application of logarithms to monetary calculations. "The way here proposed, it carries with it others [advantages] no less considerable from the helpe of Artifical Numbers or Logarithmes (the most rare \& absolute Invention for the dispatch of Arithmetical Operations that ever was or perhaps ever will be discovered) which are applicable only to this decimal way" ("Ten to One", page 5).

The final stimulus to Wood's proposal came from his involvement with the circle of philanthropists and economic reformers advising Cromwell. This group, headed by Samuel Hartlib, were convinced that technological innovation could solve many of the nation's economic problems. The informal economic debate organized by Hartlib involved Benjamin Worsley, Secretary of the Commonwealth Council of Trade, the influential merchant Henry Robinson, the pamphleteer William Potter and the young William Petty. Wood, already a friend of Petty at Oxford, joined this circle. His first letter

* The Hartlib Papers are quoted by permission of their owner, Lord Delamere. to Hartlib, dated 1-11 March 1656, enclosed the pamphlet "Ten to One".

This proposal was addressed to Cromwell and his advisers, arguing that monetary reform should rest on the principles of mathematics. Wood optimistically suggested that little cost would be involved in the decimalization of currency. The prevalent duodecial system based on shillings, pence and farthings (20th, 240th and 960th parts of a pound) was not only at odds with general methods of computation, but it also caused "distraction of the mind, and consequently pronenes to mistake". This prevented merchants readily casting accounts or checking for errors made by their employees. With the adoption of decimalization the merchants would save labour and find accountancy "turn'd to a delightfull recreation" ("Ten to One", page 3).

The pound was to remain the standard for currency. Three inferior coins were proposed; "tenths" equivalent to two shillings; "hunds" worth about two pence; finally "thous" valued at a little less than a farthing. The pound would thus be divided into ten tenths, 100 hunds and 1,000 thous, foreshadowing the most popular Victorian proposal and the one now adopted, with the elimination of the lowest value ("Ten to One", page 3).

Wood was sure that this system would be readily comprehended by the educated classes and would not prove too difficult for the rest. Any difficulties were outweighed by this rational system which would ultimately yield economic advantages. The first practical step urged by Wood was the introduction of tenths, bearing the "image and superscription" of Cromwell. Coins were indeed introduced bearing Cromwell's image, but no two-shilling piece was produced until 1849, when the florin appeared. The hund has not materialized until February 1971, while the thou has been rendered unnecessary by inflation.

While there is no evidence about official reaction to Wood's proposals, probably due to preoccupation with more immediate and serious economic problems, "Ten to One" was distributed among prominent parliamentarians and economists. In 1657, Wood reported to Hartlib, in a letter of August 1, that his scheme was accepted by the "Mathematical Professors and others" at Oxford, as well as Petty and Miles Symner in Dublin ${ }^{4}$. Thus his idea was accepted by the most influential scientific circle of the protectorate, the "Oxford group", which included Wallis, Ward, Wilkins and Wren. This was at least sufficient to keep the decimalization proposal alive. Thus two brief decimalization schemes were proposed during the vigorous debate on monetary theory at the end of the century. Significantly one came from Wren, who may have remembered Wood's original suggestion ${ }^{5}$. Perhaps the only immediate outcome of "Ten to One" and Wood's other economic speculations was a successful career in Cromwell's civil service.

1 Hartlib Papers, manuscripts in Sheffield University Library, Bundle XXVII, section 20.

2 Wood, A., Alumni Oxoniensis (edit. by Bliss, P.), 4, 167 (1820); Aubrey, J., Brief Lives (edit. by Clark, A.), 1, 120, 290; 2, 113, 141 (Oxford, 1898); Mathews, A. G., Calamy Revised, 542 (Oxford, 1934); Dictionary of National Biography, 62, 372. Taylor, E. G. R., The Mathematical Practitioners of Tudor and Stuart England, 226, 347 (Cambridge University Press, 1954).

3 The Key of Mathematicks New Forged and Filed (London, 1647).

4 Hartlib Papers, manuscripts in Sheffield University Library, Bundle XXXIII, section 1.

5 Horsefield, J. K., British Monetary Experiments 1650-1710, 292, 325 (Harvard University Press, 1960); Sir Christopher Wren's Proposal [1695]. 